\title{
BERCERITA DENGAN MEDIA WAYANG KULIT UNTUK MENINGKATKAN PEMAHAMAN TINGKAT TUTUR BAHASA JAWA SISWA SMP DI KABUPATEN MAGELANG
}

\author{
Budhi Setiawan, Nugraheni Eko Wardani, dan Kundharu Saddhono \\ Universitas Sebelas Maret \\ Email: buset.74@gmail.com
}

\begin{abstract}
Abstrak
Bahasa merupakan komponen yang tidak dapat dipisahkan dalam proses pembelajaran. Empat keterampilan berbahasa, yaitu menyimak, berbicara, membaca, dan menulis diajarkan dalam pembelajaran bahasa bersamaan dengan pembelajaran sastra. Keberhasilan suatu pembelajaran ditentukan oleh cara guru dalam menyampaikan materi pelajaran. Salah satu komponen yang dapat mendukung keberhasilan belajar siswa adalah pemilihan media pembelajaran yang digunakan. Media wayang kulit merupakan media grafis yang menggambarkan karakter berwujud wayang. Visualisasi dari media wayang yang menarik dapat mendorong siswa untu aktif memperhatikan dengan indra penglihatannya, sementara itu penyampaian materi dengan cara mendongeng dapat mendorong siswa lebih aktif dalam mendengaran dengan indranya. Dialog yang terdapat dalam wayang juga mencerminkan suatu tingkat tutur bahasa Jawa yang sesuai dengan unggah-ungguh basa Jawa. Bahasa Jawa merupakan salah satu bahasa yang memilki tingkat tutur, yaitu terdiri dari ragam ngoko, krama, dan krama inggil. Dengan menggunakan media wayang kulit, siswa dilatih agar memilki keterampilan bercerita dan membawakan karakter wayang sesuai tokoh wayang kulit yang dibawakan. Masing-masing tokoh memiliki gaya berbicara yang berbeda atau disebut dengan antawacana. Dialog dalam wayang kulit juga mencerminkan penggunaan ragam bahasa Jawa yang sesuai dengan tingkat tutur bahasa Jawa atau disebut dengan istilah undha-usuk basa Jawa. Target luaran dari kegiatan pengabdian ini untuk lebih melatih kemampuan bercerita dan mendongeng siswa dengan menggunakan media wayang kulit. Siswa dapat memiliki keterampilan bercerita yang baik apabila dapat membawakan dialog masing-masing karakter wayang kulit sesuai dengan tingkat tutur bahasa Jawa. Tujuan dari penelitian ini dibagi menjadi dua, yaitu tujuan jangka pendek dan tujuan jangka panjang. Tujuan jangka pendek, siswa SMP di Kabupaten Magelang dapat memiliki keterampilan bercerita yang baik, utamanya dapat membawakan karakter wayang sesuai antawacana masing-masing tokoh wayang. Selain itu, siswa dapat memiliki pemahaman mengenai penggunaan ragam bahasa Jawa sesuai dengan konteks tuturan dari dialog yang sedang dibawakan. Sehingga dalam proses pembelajaran bahasa Jawa dapat terjalin suatu kegiatan pembelajaran yang menggunakan ragam bahasa Jawa yang baik dan benar sesuai tingkat tutur bahasa Jawa atau disebut dengan istilah undha-usuk basa Jawa. Pelaksanaan PKM ini direncakan dalam 3 tahap, yaitu tahap persiapan, tahap pelaksanaan, dan tahap evaluasi, target luaran kegiatan pengabdian di SMP di Kabupaten Magelang ini dijabarkan menjadi dua bagian, yaitu produk kegaitan PKM yang terdiri buku modul atau bahan ajar mengenai peningkatan keterampilan bercerita siswa menggunakan media wayang kulit dan video bahan ajar keterampilan bercerita berbasis budaya Jawa. Selanjutnya, Keberhasilan PKM ini juga tentunya berdampak pada Universitas Sebelas Maret. Kegiatan ini mencerminkan bahwa salah satu tanggung jawab perguruan tinggi terhadap masyarakat tewujud dalam kegiatan PKM ini, khususnya yang berkaitan dengan sosialisasi produk budaya Jawa, yaitu wayang kulit dan penggunaan ragam bahasa Jawa yang sesuai dengan tingkat tutur bahasa Jawa yang baik dan benar.
\end{abstract}


Kata kunci: Bahasa Jawa, SMP, Tingkat Tutur, Pembelajaran

\section{PENDAHULUAN}

Kegiatan pembelajaran di sekolah tentu erat kaitannya dengan proses berbahasa. Informasi berupa materi pelajaran disampaikan oleh guru sebagai penutur kemudian diterima oleh siswa sebagai mitra tutur. Guru dalam menyampaikan materi harus jelas dan dengan bahasa yang dapat dimengerti oleh siswa. Cara penyampaian materi kepada siswa harus menarik sehingga siswa dapat menerima materi dengan maksimal. Keefektifan penyampaian materi kepada siswa dapat dilakukan dengan menggunakan media dan metode yang sesuai dengan materi yang diajarkan (Saddhono, 2014).

Penyampaian materi pembelajaran dengan menggunakan metode yang inovatif mampu membentuk suasana pembelajaran yang lebih menyenangkan. Keaktifan siswa dalam belajar juga dapat ditumbuhkan dengan penggunaan metode yang inovatif. Suasana pembelajaran yang menyenangkan dan keaktifan siswa dalam belajar mendukung kemudahan penerimaan materi yang diajarkan. Siswa yang aktif bertanya maupun menjawab pertanyaan mengindikasikan perhatian siswa yang baik terhadap proses pembelajaran.

Selain dari pemilihan metode yang tepat, keefektifan proses belajar-mengajar juga ditentukan dari pemilihan media dalam proses belajar juga dapat mempengaruhi kelancaran arus informasi yang disampaikan. Pemilihan media yang tepat mempermudah siswa dalam menangkap materi pelajaran. Hal ini sesuai dengan pernyataan Sanaky (2011:4) bahwa media pembelajaran adalah sarana pendidikan yang dapat digunakan sebagai perantara dalam proses pembelajaran untuk mempertinggi efektifitas dan efisiensi dalam mencapai tujuan pengajaran. Pendapat tersebut juga diperkuat dengan pernyataan Soeharto (2003:99) bahwa penggunaan media secara kreatif akan memperbesar kemungkinan siswa untuk belajar lebih banyak, mencamkan apa yang dipelajarinya lebih baik, dan meningkatkan penampilan mereka dalam melakukan keterampilan-keterampilan tertentu sesuai dengan apa yang menjadi tujuan pembelajaran yang telah ditetapkan.

Media pembelajaran membantu siswa lebih aktif dalam belajar. Hal ini disebabkan karena media yang digunakan memungkinkan siswa merespon pelajaran tidak hanya menggunakan satu indra saja. Hal ini sesuai dengan pendapat Saberan (2012: 1) bahwa sarana belajar sangat diperlukan dalam proses belajar mengajar karena dapat memberikan, rangsangan 
dan pengalaman belajar secara menyeluruh bagi siswa melalui semua indera, terutama indera pandang dengar. Penggunaan media audio visual tentu lebih menarik dan mudah diterima dibandingkan dengan pengajaran dengan metode yang hanya mengandalkan tuturan saja.

Salah satu alternatif media pembelajaran yang dapat digunakan dalam proses belajar adalah media wayang kulit. Media ini merupakan sebuah media grafis yang menggambarkan karakter berwujud wayang. Media wayang kulit dapat digunakan untuk meningkatkan kemampuan bercerita siswa. Hal ini dikarenakan dengan media wayang kulit dapat meningkatkan keaktifan siswa dengan membawakan karakter masiang-masing wayang yang sesuai dengan antawacana atau gaya dialog karakter wayang kulit yang berbeda-beda. Penggunaan media wayang kulit tersebut dapat mendorong suasana pembelajaran yang menyenangkan. Visualisasi dari shadow puppet yang menarik dapat mendorong siswa untuk aktif memperhatikan dengan indra penglihatannya, sementara itu penyampaian materi dengan cara mendongeng dapat meningkatkan keterampilan bercerita siswa yang disesuaikan dengan unggah-ungguh bahasa Jawa.

Bahasa Jawa merupakan salah satu bahasa yang memiliki sistem tingkat tutur yang disesuaikan dengan mitra tuturnya. Kaidah tingkat tutur bahasa Jawa disebut dengan unggahungguh basa atau undha-usuk basa yang terdiri dari beberapa ragam, seperti ragam ngoko, krama, dan krama inggil. Dalam dialog wayang atau antawacana sudah pasti menggunakan ragam bahasa Jawa yang baik dan benar. Hal ini dikarenakan wayang kulit merupakan salah satu wujud budaya Jawa yang lebih mengedepankan penggunaan ragam bahasa Jawa yang baik dan benar. Oleh karenanya, dengan mengunakan media wayang kulit siswa diharapkan memiliki keterampilan menggunakan ragam bahasa Jawa yang sesuai dengan kaidah tingkat tutur bahasa Jawa yang baik dan benar. Dengan demikian siswa akan terbiasa menggunakan ragam bahasa Jawa yang sesuai dengan unggah-ungguh basa Jawa yang baik dan benar dalam komunikasi sehari-hari.

\section{METODE}

Kegiatan pengabdian ini dilaksanakan di dua lokasi yang berbeda. Treatmen yang diberikan pada masing-masing lokasi akan dilaksanakan secara terpisah. Pengabdian tersebut akan dilaksanakan di SMPN 1 Ngablak dan SMPN 1 Pakis. Alasan pemilihan kedua sekolah tersebut adalah bahasa yang digunakan oleh siswa dari dua sekolah tersebut memiliki latar belakang penggunaan bahasa yang sama. Survey awal juga menunjukkan bahwa siswa di kedua 
sekolah tersebut masih kurang memiliki pemahaman mengenai tingkat tutur bahasa Jawa yang baik dan benar.

\section{HASIL DAN PEMBAHASAN}

Pelaksanaan PKM ini direncanakan dalam 3 tahap besar yang masing-masing mempunyai bentuk kegiatan yang berbeda. Tahapan tersebut yaitu Tahap Persiapan; Tahap persiapan ini berkaitan dengan hal yang perlu dipersiapkan dalam rangka pelaksanaan PKM ini. Persiapan awal yang dilakukan adalah survei awal ke tempat atau lokasi PKM untuk mendapatkan data awal. Setelah mendapatkan data awal baru menyusun rencana kegiatan PKM sesuai dengan kondisi permasalahan di lokasi PKM dalam hal ini berkaitan dengan kemampuan penggunaan bahasa Jawa para generasi muda yang terdapat di SMPN 1 Ngablak dan SMPN 1 Pakis. Pada tahap ini juga dilakukan perekrutan mahasiswa yang kompeten untuk mendampingi masyarakat untuk melaksanakan PKM yang akan dilakukan.

Tahap Pelaksaaan; Tahap pelaksanaan adalah inti dari PKM ini yang akan dilakukan dosen, mahasiswa, dan tim pengabdian di kedua sekolah tempat kegiatan PKM. Hasil atau data yang diperoleh pada saat survey awal kemudian dianalisis dan digunakan sebagai bahan acuan untuk mengadakan pelatihan kemampuan bercerita dengan menggunakan metode wayang kulit untuk meningkatkan pemahaman mengenai tingkat tutur bahasa Jawa yang baik dan benar. Dalam proses pelatihan siswa dan guru diberikan pengarahan mengenai tata cara mengimplementasikan media wayang kulit dalam kegiatan pembelajaran di kelas utamanya untuk meningkatkan keterampilan bercerita siswa. Siswa dilatih untuk dapat membawakan karakter masing-masing tokoh wayang sesuai dengan antawacana atau warna dialog tokoh wayang. Selain itu, siswa juga diberikan pemahaman mengenai tata cara penggunaan dan pemilihan ragam bahasa yang sesuai dengan kaidah tingkat tutur bahasa Jawa yang baik dan benar.

Tahap Evaluasi; Tahap akhir dalam kegiatan PKM ini adalah berupa evaluasi. Tahap evaluasi ini ditujukan terutama terhadap program yang dilaksanakan yaitu pelatihan bercerita dengan media wayang kulit untuk meningkatkan pemahaman tingkat tutur bahasa Jawa siswa SMP di Kabupaten Magelang. Pelaksanaan dan objek pelaksanaan PKM juga harus dievaluasi untuk mendapatkan hasil dan dampak yang signifikan kepada masyarakat khususnya pada siswa supaya memiliki pemahaman yang baik mengenai tata cara pemilihan ragam bahasa Jawa yang disesuaikan dengan kaidah tingkat tutur bahasa Jawa. Hal ini juga dijadikan dasar untuk 
menyusun modul dan artikel sebagai luaran dalam kegiatan PKM di Kabupaten Magelang.

Target dan luaran PKM ini dapat dijabarkan menjadi dua hal, yaitu produk kegiatan PKM dan hasil program PKM. Adapun jabaran dari luaran tersebut adalah indikator tercapainya kegiatan ini sudah dirumuskan oleh tim pelaksana PKM. Adapun indikator capaian program kegiatan PKM yang dilaksanakan di SMP di Kabupaten Magelang yaitu Guru dan Siswa Sekolah Menengah Pertama di Kabupaten Magelang dapat memperoleh pemahaman mengenai unggah-ungguh basa dalam bahasa Jawa (ngoko, krama, dan krama inggil). Hal tersebut berguna bagi guru dan siswa untuk digunakan dalam komunikasi sehari-hari yang sesuai dengan kaidah tingkat tutur bahasa Jawa yang baik dan benar. Guru dapat mengimplementasikan media wayang untuk meningkatkan keterampilan bercerita siswa SMP di Kabupaten Magelang. Siswa dapat mengenal antawacana atau karakter berbicara dari masing-masing tokoh wayang yang dibawakan, selanjutnya hal ini dapat digunakan dasar mereka dalam bercerita sesuai dengan antawacana atau warna dialog dari masing-masing tokoh wayang. Para siswa dapat membiasakan menggunakan ragam bahasa yang sesuai dengan kaidah tingkat tutur bahasa Jawa yang baik dan benar dalam kegiatan proses pembelajaran, baik ketika berbicara dengan teman sebaya maupun ketika berbicara dengan guru. Guru dan siswa berperan aktif dalam kegiatan pelestarian terhadap salah satu produk budaya Jawa, yaitu wayang kulit.

Produk Kegiatan PKM adalah Modul atau buku pedoman mengenai penggunaan media wayang kulit dalam pembelajaran di kelas untuk menumbuhkan pemahaman mengenai tingkat tutur bahasa Jawa yang baik dan benar. Artikel jurnal pengabdian mengenai kegiatan pelatihan bercerita dengan media wayang kulit untuk meningkatkan pemahaman tingkat tutur bahasa Jawa siswa SMP di Kabupaten Magelang.

Hasil Program PKM adalah kegiatan pelatihan bercerita dengan media wayang kulit untuk meningkatkan pemahaman tingkat tutur bahasa Jawa siswa SMP di Kabupaten Magelang, dijabarkan dalam 2 bagian, yaitu hasil kegiatan jangka pendek dan jangka panjang. Secara garis besar hasil kegiatan ini dapat dijabarkan yaitu dalam jangka pendek, guru SMP di Kabupaten Magelang dapat memperoleh pengertian mengenai tata cara mengimplementasikan media wayang kulit untuk meningkatkan keterampilan bercerita dan pemahaman mengenai tingkat tutur bahasa Jawa siswa SMP di Kabupaten Magelang. Hal ini diharapkan guru dapat mendesain pembelajaran menjadi lebih menarik dan efektif dengan menggunakan media wayang kulit sehingga keterampilan bercerita siswa dapat meningkat dan siswa dapat 
memperoleh pengetahuan mengenai tata cara penggunaan ragam bahasa Jawa yang baik dan benar sesuai kaidah tingkat tutur bahasa Jawa.

Dalam jangka panjang, pelatihan ini dapat terus dilakukan untuk memberikan pendidikan berkelanjutan yang ditujukan kepada guru dan siswa di SMP di Magelang untuk dapat mengimplementasikan pembelajaran bahasa Jawa dengan menggunakan salah satu produk dari budaya Jawa, yaitu wayang kulit. Selanjutnya, guru dan siswa SMP di Kabupaten Magelang dapat menumbuhkembangkan sikap positif terhadap bahasa Jawa dan mengimplementasikan tidak hanya dalam proses pembelajaran, tetapi juga dalam kegiatan sehari-hari.

\section{KESIMPULAN}

Keberhasilan PKM ini juga memiliki peranan atau sumbangsih pada Instansi, dalam hal ini Universitas Sebelas Maret. Kegiatan pengabdian kepada masyarakat. Kegiatan pelatihan bercerita dengan media wayang kulit untuk meningkatkan pemahaman tingkat tutur bahasa Jawa siswa SMP di Kabupten Magelang ini merupakan salah satu tanggung jawab Universitas Sebelas Maret dalam melaksanakan program Tri Darma Pergurutan Tinggi. Dengan memberikan pelatihan bercerita dengan media wayang kulit untuk meningkatkan pemahaman tingkat tutur bahasa Jawa pada siswa SMP di Kabupaten Magelang bertujuan untuk menyosialisasikan mengenai tata cara penggunaan ragam bahasa Jawa yang sesuai dengan kaidah tingkat tutur bahasa Jawa yang baik dan benar. Di samping itu, program ini juga dalam rangka mengembangkan kecintaan siswa terhadap produk budaya Jawa yang berupa wayang kulit.

\section{DAFTAR PUSTAKA}

Bashir, Marriam, Muhammad Azeem, dan Ashiq Hussain Dogar. 2011. "Factor Effecting Students' English Speaking Skills”. British Journal of Arts and Social Sciences. vol. 2 (1). hlm. 36.

P., Shiny K. 2016. "Factors Affecting Learners' Oral Communication and Coping Strategies". International Journal of Academic Research. vol. 3 (2). hlm. 129.

Saberan, Riduan. 2012. "Penggunaan Media Audio Visual dalam Meningkatkan Motivasi dan Hasil Belajar Siswa”. LENTERA: Jurnal Ilmiah Kependidikan. vol. 7 (2). hal. 1. 
Saddhono, Kundharu. 2014. Pembelajaran Keterampilan Berbahasa Indonesia: Teori dan Praktik. Yogyakarta; Graha Ilmu.

Sanaky, Hujair AH. 2011. Media Pembelajaran: Buku Pegangan Wajib Guru dan Dosen. Yogyakarta: Kaukaba.

Soeharto, Karti, dkk. 2003. Teknologi Pembelajaran: Pendekatan Sistem, Konsepsi dan Model, SAP, Evaluasi, Sumber Belajar dan Media. Surabaya: Surabaya Intellectual Club. 